\title{
THE PROTECTION AFFORDED BY VARIOUS FILTERS AGAINST BACTERIAL SUSPENSIONS IN AIR
}

\author{
Richard C. Tolman, Ernest W. Guernsey, \\ VERne D. Charleston, and Robert H. Dougherty
}

The work described in this article was undertaken at the suggestion of Dr. John Johnston, secretary of the National Research Council, and Dr. Peyton Rous, vice-chairman of the Division of Medicine and Allied Sciences, with a view to selecting a filtering material which would afford adequate protection for physicians, nurses and others obliged to work in rooms, the air of which is infected with bacteria. Tests which have been previously made establish the degree of prevention given by various types of cloth masks against the projection of infectious droplets in coughing and talking, but we know of no study made on the penetration through mask materials of bacteria suspended in convection currents of air, which, whether dry or moist, are certainly not held in droplets of moisture.

\section{METHOD OF STUDY}

1. The Bacterial Cultures. - Bacillus prodigiosus was selected for these experiments because (1) the red pigment which it develops in plate cultures makes it possible to recognize accidental contamination in the plates; (2) its size, one of the chief factors influencing penetration of mask materials, is representative, and (3) it is nonpathogenic.

The cultures were prepared by inoculating sterile beef broth from a 20-day old culture which contained enough prodigiosus to impart a deep red color to the solution. One small platinum loopful of the 20-day broth culture was used for each $5 \mathrm{cc}$ of sterile broth. The new culture was incubated for 18 hours at $37.5^{\circ} \mathrm{C}$. The incubation was not continued longer because of the tendency to form clumps in the broth which might clog the atomizer in setting up the suspension. It later appeared that it would have been better to use more concentrated culture in smaller quantity and toward the end of the work a few determinations were made in which the old red 20-day culture was used.

2. The Production of Bacterial Suspensions.-The bacterial suspensions were set up in a $1 \mathrm{cu}$. $\mathrm{m}$. sheet metal box which had been previously disinfected with formaldehyd and was filled with air forced through a copper spiral heated in a bath of molten Woods metal. The suspension was formed by spraying the pure broth culture of prodigiosus in the form of a very fine mist through a hole in one corner of the box. The evaporation of the mist carrying the bacteria was facilitated by a layer of calcium chlorid spread over the floor. 
A fan directing a gentle current of air upward under the incoming spray helped to keep the bacteria in the air until they could be freed of their load of water. A preliminary warming of the broth culture to $40^{\circ} \mathrm{C}$. before spraying, helped make the evaporation of the water more rapid. Even with these refinements only a small percentage of the bacteria originally introduced were actually obtained in suspension, due to the falling out of the larger drops of the spray, the lodging of droplets and of bacteria on the side of the box, etc. The fact that all the droplets of mist sprayed into the box actually evaporated, was shown by the lack of any deposition of moisture in the glass tubes through which the samples of air to be tested were drawn from the box.

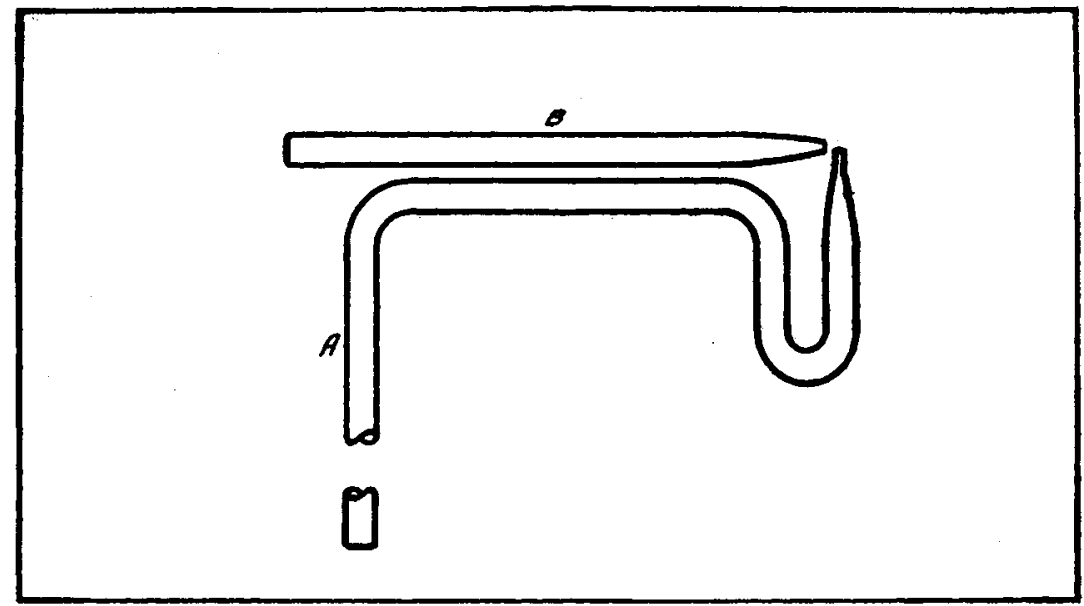

Fig. 1.-Showing the atomizer made from glass tubing used for spraying the culture into the box.

The atomizer used for spraying the culture into the box was made from glass tubing as shown in Fig. 1. The solution to be sprayed is drawn up through tube $A$ and out of the capillary by the aspirating action of a fine jet of air which is forced through the capillary of tube B. The capillary openings of the tubes were extremely fine and the particular atomizer used was selected from a number because it gave the finest spray. A Air was supplied to the atomizer at a rate of 15 liters per minute by means of a Type A Leiman Bros. pump driven by a $1 / 4 \mathrm{H}$. P. motor. To prevent contamination the air. for the aspirator was drawn from the box itself. The liquid was sprayed at a rate of approximately $10 \mathrm{cc}$ per minute.

The usual amount of the 18 -hour culture used was about $20 \mathrm{cc}$. When only $10 \mathrm{cc}$ were used the concentrations of bacteria obtained was not as high as desired; and $40 \mathrm{cc}$ gave only slightly higher concentrations of bacteria than did $20 \mathrm{cc}$. The character of the suspension was, of course, not greatly different when different amounts were used, since in any case the droplets which did not evaporate-whether because they were too large or because the box became saturated with moisture-fell out and there remained in the air only the bacteria, more or less moist.

3. The Method of Carrying Out the Test.-The general plan of the test was to draw a known volume of suspension through the filter, catching the bacteria 
which penetrated the filter in a liquid medium; and simultaneously to draw through a parallel path, not containing a filter, the same volume of suspension, catching the bacteria in this path in the same way. A comparison of the number of bacteria found in the two paths then gives a value for the percentage penetration of the filtering material. The simple apparatus used is shown in Fig. 2.

The filter is held in a standard $1 \frac{11 / 2}{2}$ pipe union in which the inside flange has been ground away smooth. The filter rests in the fitting in the same way a bushing would be held except that the filter extends across the opening. Four-inch nipples extend from each side of the union, and are fitted with rubber stoppers to receive the glass tubing which forms the rest of the path.

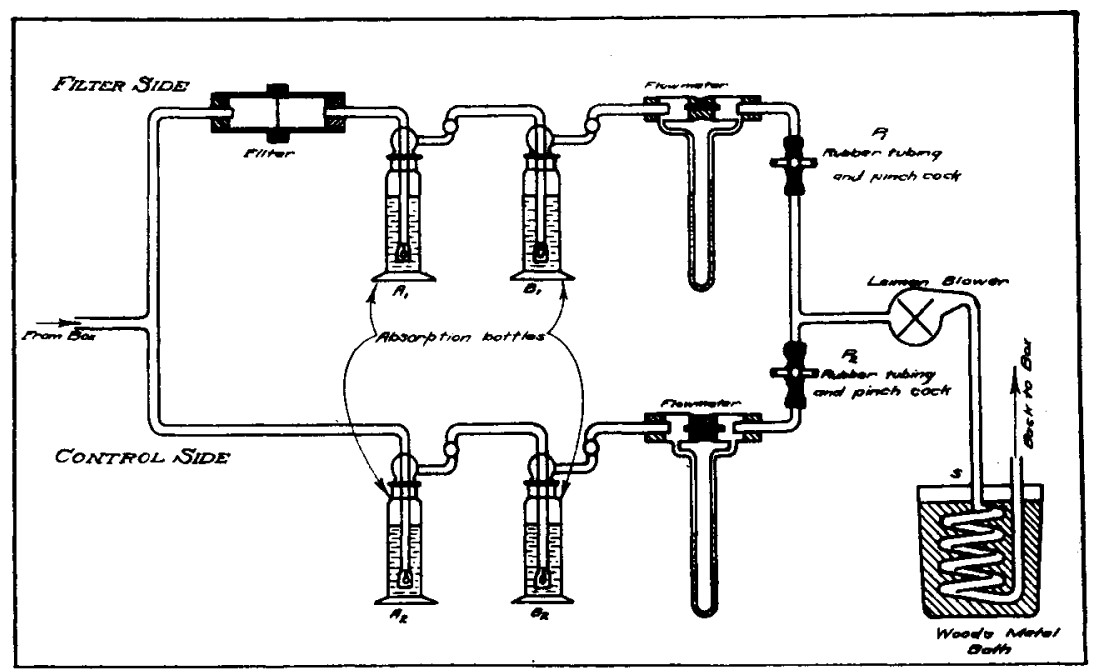

Fig. 2.-Diagram of the apparatus employed in these experiments.

The absorption bottles, $A_{1}, B_{1}, A_{2}$ and $B_{2}$ are standard gas absorption botthes of $300 \mathrm{cc}$ capacity and about $20 \mathrm{~cm}$. in height. Special apron bubblers are provided on the gas inlet tubes. Flowmeters in each path after the absorption bottles measure the flow which is kept at the proper value by means of pinch cocks $P_{1}$ and $P_{2}$. The air is pulled through the two parallel paths by means of the same Leiman blower that is used in spraying the broth culture. In order that the partial vacuum created by the drawing out of the sample will not cause contaminated air to be drawn into the box through leaks, the air drawn out is passed through the heated copper spiral (S) and back into the box. The air after passing the spiral goes through a long tube and before reaching the box cools to about $50^{\circ} \mathrm{C}$. as was shown by a thermometer.

Before each determination, all of the sampling apparatus between the box and the flowmeters was sterilized in steam at 20 pounds pressure for half an hour. The filter was afterward dried at a low temperature in the oven.

The original plan was to use beef broth as the medium for catching the bacteria. It was found, however, that beef broth frothed so badly in the absorption bottles as to make it impractical for this purpose. Physiologic salt solution was found to be satisfactory and was used in all of the determinations 
included in this report. The amount used in each of the bottles was about $200 \mathrm{c} \mathrm{c}$ or somewhat less.

The rate of flow of air through the filter used in these experiments was 6 liters per minute and the area of filtering material exposed about $12 \mathrm{sq} . \mathrm{cm}$. This rate corresponds fairly closely with the normal breathing rate over the effective area in ordinary cloth face masks and is much higher than breathing rates with areas, which can easily be obtained with masks of proper design; so that results obtained at this rate cannot be too favorable to the mask under test.

In the earlier determinations, one 10-minute sample was taken in each run, starting about one-half minute after the spray was stopped, which gave time for any remaining mist particles to settle out or evaporate. Later, however, as the technic became simplified, two samples were tested in each run, in order to see if the bacteria would become more penetrating with further chance to dry. The first sample was from 0-5 minutes after stopping the spray, and the second from 20-25 minutes. In some of the runs the fan inside the box was allowed to run throughout the test, while in others it was stopped after completing the spray and in three experiments was allowed to run while the first sample was being taken, and then stopped.

4. Plating Out the Bacteria for Counting.-As soon as possible after getting the bacteria into the salt solution in the manner outlined, aliquot portions of the solution were mixed with warm sterile beef broth containing $2 \%$ of agaragar and poured into Petri dishes of $10 \mathrm{~cm}$. diameter which had been sterilized for 1 hour in dry air at $150^{\circ} \mathrm{C}$. When it was desired to obtain a higher dilution than could be obtained by pipetting directly from the bottles, a small portion was diluted with sterile salt solution and an aliquot portion of this plated out. By repeating this dilution any proportion of the total number of bacteria which was suitable could be obtained in the Petri dish. In the earlier determinations before the approximate concentration of bacteria to be expected was known, as many as 5 different dilutions ranging from $1: 100$ to $1: 1,000,000$ were used for each of the four bottles. Later, however, 2 dilutions for each bottle were found sufficient.

The colonies developing from the bacteria in the plates were counted after 24 hours' incubation at $37.5^{\circ} \mathrm{C}$., since at this time the colonies were sufficiently developed to be seen fairly well and molds and other accidental contaminations were less confusing than later. The count was always checked at 48 hours. Calculations were based on the plates giving a count nearest 100 ; since, if the colonies were too thick, there might be a suppression of colonies, while if they were too few the error in assuming the plate to be a fair sample would be great.

In the early tests there were frequent contaminations in small amounts, apparently of Staph. aureus, Staph. albus, proteus and some molds which latter, however, developed so late as to cause no confusion. Later, with improved technic, contaminations became even less troublesome, there being many plates without any stray organisms at all.

The plating out of the bacteria was rarely delayed longer than 20 minutes after completing a sample. Two duplicate determinations were made which showed that $B$. prodigiosus was not killed in this time in the salt solution, plate cultures taken over an interval of an hour after collection of a sample failing to show any appreciable falling off in the concentration of bacteria. 


\section{FILTERS STUDIED}

The following filters were examined to determine the protection which they afforded:

1. Buttercloth masks as recommended by Doust and Lyon. ${ }^{1}$

2. Buttercloth masks as above except moistened as in wearing.

3. Buttercloth masks as above except wet.

4. A buffed felt of medium hard texture about $1 / 8$ " thick, made by the Booth Felt Co., and giving a pressure drop of about $35 \mathrm{~mm}$. of water with a flow of $500 \mathrm{cc}$ of air per sq. $\mathrm{cm}$. per minute.

5. A special buffed felt of hard texture about $5 / 32$ " thick, made by the Felters Co., of a blend of 20 California, 40 Cape and 40 Texas, and giving a pressure drop of about $130 \mathrm{~mm}$. of water with a flow of $500 \mathrm{cc}$ of air per sq. $\mathrm{cm}$. per minute.

TABLE 1

Penetration of Prodigiosus Through Medium Hard felt Sample 0-10 minutes

\begin{tabular}{c|c|c|c}
\hline & Dilution & No. Colonies & No. Bacteria in Bottle \\
\hline Control & $1: 1,400$ & 514 & 719,600 \\
Bottle A & $1: 14,000$ & 120 & $1,680,000$ \\
& $1: 140,000$ & 17 & $2,380,000$ \\
\hline Control & $1: 1,800$ & 36,000 \\
Bottle B & $1: 18,000$ & 3 & 54,000 \\
\hline Filter & $1: 1,800$ & 8 & 14,400 \\
Bottle A & $1: 18,000$ & 1 & 18,000 \\
\hline Filter & $1: 1,300$ & 0 & 0 \\
Bottle B & $1: 13,000$ & 0 & 0 \\
\hline
\end{tabular}

No. of bacteria in 60 liters of unfiltered air................. $1,716,000$

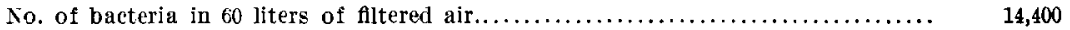

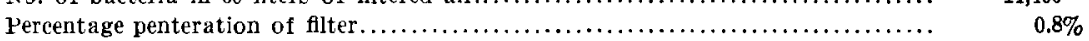

20 c c 18-hour culture was used to set up suspension. The fan in the box ran throughout the experiment.

6. An electrical precipitation tube. This apparatus is part of an "Electric Mask" developed by Dr. Arthur B. Lamb and associates. It operates on the same principle as the familiar Cottrell precipitators used to remove dust and fumes from the fuel gasses of blast furnaces and cement kilns. The apparently hopeless difficulty of securing adequate and dependable high tension electric power in a portable equipment has been solved by the development of a very light and efficient storage battery and induction coil. This equipment as at present developed will operate continuously from 6-10 hours and weighs only about 5 pounds.

\section{EXPERIMENTAL RESULTS}

The accompanying tables illustrate the tests. Filter bottle $\mathrm{A}$ and filter bottle $\dot{B}$ are the first and second absorption bottles after the

1 Jour. Am. Med. Assn., 1918, 71, p. 1216. 
TABLE 2

Penetration of Prodigiosus Through Three layers of Buttercloth Sample 0-5 minutes

\begin{tabular}{|c|c|c|c|}
\hline & Dilution & No. Colonies & No. Bacteria in Bottle \\
\hline $\begin{array}{l}\text { Control } \\
\text { Bottle A }\end{array}$ & $\begin{array}{l}1: 1,600 \\
1: 16,000\end{array}$ & $\begin{array}{r}2 ; 000 \\
250\end{array}$ & $\begin{array}{l}3,200,000 \\
4,000,000\end{array}$ \\
\hline $\begin{array}{c}\text { Control } \\
\text { Bottle B }\end{array}$ & $\begin{array}{l}1: 1,740 \\
1: 17,400\end{array}$ & $\begin{array}{r}800 \\
93\end{array}$ & $\begin{array}{l}1,392,000 \\
1,618,200\end{array}$ \\
\hline $\begin{array}{c}\text { Filter } \\
\text { Bottle A }\end{array}$ & $\begin{array}{l}1: 1,7: 00 \\
1: 17,200\end{array}$ & $\begin{array}{r}1,300 \\
143 \\
\end{array}$ & $\begin{array}{l}2,236,000 \\
2,459,600\end{array}$ \\
\hline $\begin{array}{c}\text { Filter } \\
\text { Bottle } \mathbf{B}\end{array}$ & $\begin{array}{l}1: 165 \\
1: 1,650\end{array}$ & $\begin{array}{r}221 \\
21\end{array}$ & $\begin{array}{l}36,465 \\
34,651\end{array}$ \\
\hline \multicolumn{4}{|c|}{ Sample $20-25$ minutes } \\
\hline $\begin{array}{l}\text { Control } \\
\text { Bottle A }\end{array}$ & $\begin{array}{l}1: 164 \\
1: 1,640\end{array}$ & $\begin{array}{r}50 \\
4\end{array}$ & $\begin{array}{l}8,200 \\
6,560\end{array}$ \\
\hline $\begin{array}{c}\text { Filter } \\
\text { Bottle A }\end{array}$ & $\begin{array}{l}1: 176 \\
1: 1,760\end{array}$ & $\begin{array}{r}42 \\
4\end{array}$ & $\begin{array}{l}7,392 \\
7,040\end{array}$ \\
\hline
\end{tabular}

Sample 0-5 minutes:

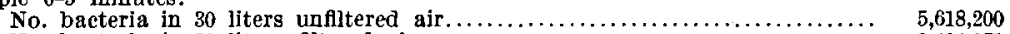

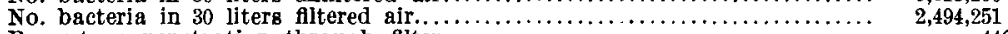

Percentage penetration through filter........................... $44 \%$ Sample 20-25 minutes:

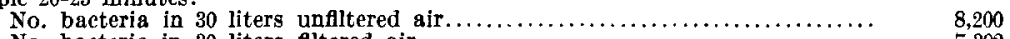

No. bacteria in 30 liters flltered air.............................. 7,392

Percentage penetration through filter............................ $90 \%$

Remarks: 20 e c 36-hour culture sprayed into box. Fan stopped after spraying.

TABLE 3

Penetration of Prodigiosus Through Three Layers of Wet Buttercloth Sample 0-5 minutes

\begin{tabular}{c|c|c|c}
\hline & Dilution & No. Colonies & No. Bacteria in Bottle \\
\hline Control & $1: 1,320$ & 69 & 91,080 \\
Bottle A & $1: 13,200$ & 7 & 92,400 \\
\hline Control & $1: 105$ & 260 & 27,300 \\
Bottle B & $1: 1,050$ & 19 & 19,950 \\
\hline Filter & $1: 123$ & 50 & 6,150 \\
Bottle A & $1: 1,230$ & 10 & 12,300
\end{tabular}

Sample 20-25 minutes

\begin{tabular}{c|c|c|c}
$\begin{array}{c}\text { Control } \\
\text { Bottle A }\end{array}$ & $1: 156$ & 195 & \multicolumn{3}{c}{30,420} \\
34,320 \\
\hline Filter & $1: 1,560$ & 22 & 1,274 \\
Bottle A & $1: 182$ & 7 & 1,820 \\
\hline
\end{tabular}

Sample 0-5 minutes:

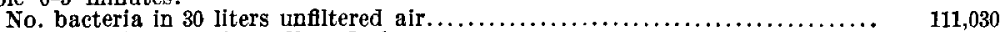

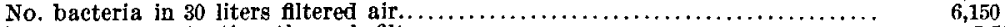

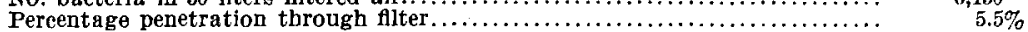

Sample 20-25 minutes:

No. bacteria in 30 liters unfiltered air $\ldots \ldots \ldots \ldots \ldots \ldots \ldots \ldots \ldots \ldots \ldots \ldots \ldots \ldots \ldots \ldots \ldots \ldots \ldots \ldots \ldots \ldots \ldots \ldots \ldots \ldots \ldots \ldots \ldots$
No. bacteria in 30 liters fltered air.

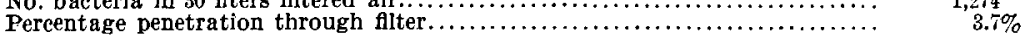

Remarks: The filter was wet by spraying water onto it just before the experiment. Exam. ination just after determination showed it to be thoroughly saturated with water. $10 \mathrm{cc}$ of 18-hour culture was sprayed to produce the suspension. The fan ran throughout the experiment. 
TABLE 4

Penetration of Prodigiosus Through the Electrical. Precipitation tube Sample $0-5$ minutes

\begin{tabular}{|c|c|c|c|}
\hline & Dilution & No. Colonies & No. Bacteria in Bottle \\
\hline $\begin{array}{c}\text { Control } \\
\text { Bottle } \mathrm{A}\end{array}$ & $\begin{array}{l}1: 1,550 \\
1: 15,500\end{array}$ & $\begin{array}{r}3,000 \\
400\end{array}$ & $\begin{array}{l}4,650,000 \\
6,200,000\end{array}$ \\
\hline $\begin{array}{l}\text { Control } \\
\text { Bottle B }\end{array}$ & $\begin{array}{l}1: 1 \% 6 \\
1: 1,760\end{array}$ & $\begin{array}{r}5,000 \\
550\end{array}$ & $\begin{array}{l}880,000 \\
968,000\end{array}$ \\
\hline $\begin{array}{c}\text { Filter } \\
\text { Bottle A }\end{array}$ & $\begin{array}{l}1: 120 \\
1: 1,200\end{array}$ & $\begin{array}{l}0 \\
0\end{array}$ & $\begin{array}{l}0 \\
0\end{array}$ \\
\hline $\begin{array}{c}\text { Filter } \\
\text { Bottle } \mathbf{B}\end{array}$ & $\begin{array}{l}1: 170 \\
1: 1,700\end{array}$ & $\begin{array}{l}0 \\
0\end{array}$ & $\begin{array}{l}0 \\
0\end{array}$ \\
\hline \multicolumn{4}{|c|}{ Sample $20-25$ minutes } \\
\hline $\begin{array}{c}\text { Control } \\
\text { Bottle A }\end{array}$ & $\begin{array}{l}1: 160 \\
1: 1,600\end{array}$ & $\begin{array}{r}1,800 \\
207\end{array}$ & $\begin{array}{l}288,000 \\
331,200\end{array}$ \\
\hline $\begin{array}{c}\text { Filter } \\
\text { Bottle A }\end{array}$ & $\begin{array}{l}1: 160 \\
1: 1,600\end{array}$ & $\begin{array}{l}0 \\
0\end{array}$ & $\begin{array}{l}0 \\
0\end{array}$ \\
\hline
\end{tabular}

Sample 0-5 minutes:

No. bacteria in 30 liters unfltered air. $\ldots \ldots \ldots \ldots \ldots \ldots \ldots \ldots \ldots \ldots \ldots \ldots \ldots, \quad 7,168,000$

No. bacteris in 30 liters fltered air....

Percentage penetration through filter.

Sample 20-25 minutes:

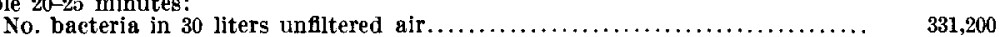

No. bacteria in 30 liters flitered air......

331,200
0

Percentage penetration through filter...

$0 \%$

Remarks: 5 e e of old red culture was sprayed for the suspension. The fan ran throughout the experiment.

TABLE 5

Penetration of Prodigiosus Through Hard Felt Sample 0-5 minutes

\begin{tabular}{|c|c|c|c|}
\hline & Dilution & No. Colonies & No. Bacteria in Bottle \\
\hline $\begin{array}{l}\text { Control } \\
\text { Bottle A }\end{array}$ & $\begin{array}{l}1: 2,080 \\
1: 20,800\end{array}$ & $\begin{array}{r}3,000 \\
353\end{array}$ & $\begin{array}{l}6,240,000 \\
7,342,400\end{array}$ \\
\hline $\begin{array}{l}\text { Control } \\
\text { Bottle B }\end{array}$ & $\begin{array}{l}1: 2,020 \\
1: 20,200\end{array}$ & $\begin{array}{r}361 \\
43\end{array}$ & $\begin{array}{l}729,220 \\
868,600\end{array}$ \\
\hline $\begin{array}{c}\text { Filter } \\
\text { Bottle A }\end{array}$ & $\begin{array}{l}1: 202 \\
1: 202\end{array}$ & $\begin{array}{l}0 \\
0\end{array}$ & $\begin{array}{l}0 \\
0\end{array}$ \\
\hline
\end{tabular}

Sample 20-25 minutes

\begin{tabular}{|c|c|c|c|}
\hline $\begin{array}{c}\text { Control } \\
\text { Bottle } \mathbf{A}\end{array}$ & $\begin{array}{l}1: 1,840 \\
1: 18,400\end{array}$ & $\begin{array}{r}103 \\
8\end{array}$ & $\begin{array}{l}189,520 \\
147,200\end{array}$ \\
\hline $\begin{array}{c}\text { Filter } \\
\text { Bottle A }\end{array}$ & $\begin{array}{l}1: 200 \\
1: 200\end{array}$ & $\begin{array}{l}0 \\
0\end{array}$ & $\begin{array}{l}0 \\
0\end{array}$ \\
\hline
\end{tabular}

Sample 0-5 minutes:

No. Bacteria in 30 liters unfiltered air.

No, bacteria in 30 liters fltered air...

$8,211,000$

Percentage penetration through flter

Sample 20-25 minutes:

No. bacteria in 30 liters unfiltered air.

No. bacteria in 30 liters filtered air...

Percentage penetration through filter.

five minutes only. 
filter, and control bottles $\mathrm{A}$ and $\mathrm{B}$ are the absorption bottles in the parallel path in which there is no filter. From the number of colonies actually counted and the dilution, both of which are given in the table, the number of bacteria present in each bottle is calculated. Since bottles $A$ and $B$ are in series on both the filter and the control side, the results for the bottles $A$ and $B$ in both sets are additive. As explained earlier, the counts on which the penetration calculation is based are those nearest 100 colonies per plate.

Table 6 gives in summary the results on the various filters studied.

TABLE 6

The Penetration of Bacillus Prodiglosus Through Filters

\begin{tabular}{|c|c|c|c|c|c|c|c|}
\hline \multirow[b]{2}{*}{ Test } & \multirow[b]{2}{*}{ Filter } & \multicolumn{2}{|c|}{$\begin{array}{l}\text { First Sample } \\
0-5 \text { Minutes }\end{array}$} & \multicolumn{3}{|c|}{$\begin{array}{l}\text { Second Sample } \\
20-25 \text { Minutes }\end{array}$} & \multirow[b]{2}{*}{ Remarks } \\
\hline & & $\begin{array}{c}\text { Bacteria } \\
\text { per } \\
\text { Liter } \\
\text { Original } \\
\text { Air }\end{array}$ & $\mid \begin{array}{c}\text { Per- } \\
\text { centage } \\
\text { Bacteria } \\
\text { Passing } \\
\text { Filter }\end{array}$ & $\begin{array}{l}\text { Bacteria } \\
\text { per } \\
\text { Liter } \\
\text { Original } \\
\text { Air }\end{array}$ & $\begin{array}{l}\text { Per- } \\
\text { centage } \\
\text { Original } \\
\text { Concen- } \\
\text { tration }\end{array}$ & $\begin{array}{c}\text { Per- } \\
\text { centage } \\
\text { Bacteria } \\
\text { Passing } \\
\text { Filter }\end{array}$ & \\
\hline $\begin{array}{l}\mathrm{V} \\
\cdot\end{array}$ & $\begin{array}{c}3 \text { layers } \\
\text { buttercloth }\end{array}$ & 73,250 & 73 & 185 & 0.25 & 85 & $\begin{array}{l}20 \text { c c } 18 \text {-hour cul- } \\
\text { ture. Fan stopped } \\
\text { after spraying }\end{array}$ \\
\hline VI & $\begin{array}{c}3 \text { layers } \\
\text { but tercloth }\end{array}$ & 38,430 & 50 & 272 & 0.71 & 76 & $\begin{array}{c}20 \text { c e } 18 \text {-hour cul- } \\
\text { ture. Fan ran } \\
\text { throughout }\end{array}$ \\
\hline$\underset{\text { ('Table 2) }}{\text { VII }}$ & $\begin{array}{l}3 \text { layers } \\
\text { buttercloth }\end{array}$ & 187,273 & 44 & 273 & 0.15 & 90 & $\begin{array}{c}20 \text { e e } 36 \text {-hour cul- } \\
\text { ture. Fan stopped } \\
\text { after spraying }\end{array}$ \\
\hline XIII & $\begin{array}{c}3 \text { layers } \\
\text { buttercloth } \\
\text { moistened as } \\
\text { in wearing }\end{array}$ & 31,320 & 28.5 & 3,103 & 10.0 & 21 & $\begin{array}{l}20 \text { c c } 18 \text {-hour cul- } \\
\text { ture. Fan stopped } \\
5 \text { minutes after. } \\
\text { spraying }\end{array}$ \\
\hline $\begin{array}{c}\text { VIII } \\
\text { (Table 3) }\end{array}$ & $\begin{array}{c}3 \text { layers } \\
\text { buttercloth } \\
\text { saturated } \\
\text { with water }\end{array}$ & 3,701 & 5.5 & 1,144 & 30.0 & 3.7 & $\begin{array}{l}10 \text { c c } 18-\text { hour cul- } \\
\text { ture. Fan ran } \\
\text { throughout }\end{array}$ \\
\hline$\underset{\text { (Table I) }}{\mathrm{I}}$ & Medium felt & $\begin{array}{l}\text { Sample } \\
28,600\end{array}$ & $0-10 \min$. & $\ldots \ldots$ & $\cdots$ & $\ldots$ & $\begin{array}{c}20 \text { c c } 18 \text {-hour cul- } \\
\text { ture. Fan ran } \\
\text { throughout }\end{array}$ \\
\hline $\mathrm{III}$ & Medium felt & 222,173 & 0.35 & 481 & 0.21 & 8.5 & $\begin{array}{l}20 \text { c e } 72 \text {-hour cul- } \\
\text { ture. Fan stopped } \\
\text { after spraying }\end{array}$ \\
\hline III & Medium felt & $9,5 d 1$ & 0.61 & 553 & 5.8 & 2 & $\begin{array}{l}40 \mathrm{cc} 18 \text {-hour cul- } \\
\text { ture. Fan stopped }\end{array}$ \\
\hline IV & Medium felt & 232,750 & 4.5 & 70,433 & 30.0 & 2.5 & $\begin{array}{l}\text { after spraying } \\
5 \text { e old red eul- } \\
\text { ture. Fan ran }\end{array}$ \\
\hline IX & Hard felt & 2,562 & 0 & 133 & 5.2 & 0 & $\begin{array}{ll}10 \mathrm{ce} & 18-h o u r \\
\text { cul- } \\
\text { ture. Fan ran }\end{array}$ \\
\hline XII & Hard felt & 5,404 & 0 & 6 & 0.1 & 0 & $\begin{array}{l}20 \text { c c 18-hour cul- } \\
\text { ture. Fan stopped } \\
5 \text { minutes after } \\
\text { spraying }\end{array}$ \\
\hline $\begin{array}{l}\text { XIV } \\
\text { (Table 5) }\end{array}$ & Hard feIt & 273,700 & 0 & 6,317 & 2.3 & 0 & $\begin{array}{l}5 \text { c e old red cul- } \\
\text { ture. Fan stopped } \\
5 \text { minutes after } \\
\text { spraying }\end{array}$ \\
\hline$\underset{(\text { Table 4) }}{\mathrm{X}}$ & $\begin{array}{l}\text { Electrical } \\
\text { precipita- } \\
\text { tion tube }\end{array}$ & 238,933 & 0 & 11,040 & 4.6 & 0 & $\begin{array}{l}5 \text { ce old red cul- } \\
\text { ture. Fan ran } \\
\text { throughout }\end{array}$ \\
\hline XI & $\begin{array}{l}\text { Electrical } \\
\text { precipita- } \\
\text { tion tube }\end{array}$ & 131,213 & 0 & 17,520 & 13.0 & 0 & $\begin{array}{l}5 \text { ce old red cul- } \\
\text { ture. Fan ran } \\
\text { throughout }\end{array}$ \\
\hline
\end{tabular}


1, 2 and 3. Buttercloth Masks Recommended by Doust and Lyon.These masks consist of three layers of buttercloth, a closely woven gauze. They were shown by Doust and Lyon to prevent completely the projection of infectious material by a person wearing the mask. Our investigation shows, however, that they are by no means adequate protection to the wearer against bacteria which having become freed from their envelop of water, are swept up in the air by convection currents. A penetration of from 44 to $73 \%$ was observed for the more moist 0-5 minute sample, while for the 20-25 minute drier sample, $76 \%$ penetration was the lowest value observed. In these tests, care was taken that the fabric should be held loosely as in wearing and not stretched. Our results show that moistening the buttercloth increases the filtering efficiency of these masks. A degree of moisture similar to that which might in extreme cases obtain in wearing, lowers the penetration of the buttercloth to $29 \%$. One determination was made with the buttercloth saturated with water in order to exaggerate this effect and in this case a penetration of only $5.6 \%$ was found.

4. Medium Hard Felt.-This felt affords almost perfect protection against bacterial suspensions. From 2 to $4 \%$ penetration is the maximum under the most favorable conditions.

5. Hard Felt.-This felt affords complete protection against suspensions of $\mathrm{B}$. prodigiosus under every condition.

6. Electrical Precipitation Tube.--In two duplicate determinations, made in the same way as the determinations on the cloth filters, the portable electrical precipitation mask developed by Dr. Arthur B. Lamb was found to prevent completely the passage of live bacteria. To find out whether the bacteria were killed in the action of the precipitating tube, the tube was rinsed out after a test with $100 \mathrm{c} \mathrm{c}$ sterile salt solution and portions plated out with beef broth and agar-agar in four different dilutions. All four plates remained entirely blank showing that the bacteria are killed by the electrical precipitation tube.

THE BACTERIAL CONCENTRATIONS ACHIEVED AND THE
PERSISTENCE OF BACTERIAL SUSPENSIONS

It perhaps will be noticed that there are wide variations in the bacterial concentrations attained under apparently parallel conditions. Thus the concentration given by $20 \mathrm{cc}$ of 18 -hour culture sprayed into the box, varies from 5,404 bacteria per liter to 73,250 bacteria 
per liter. This variation was due to various factors such as variation in the concentration of the mother culture used in inoculating, differences in the temperature of the box, differences in the efficiency of the spray due to the partial clogging by clumps in some instances, and perhaps other factors.

In the early tests portions of the culture to be sprayed were plated out in several dilutions in order to get an idea of the maximum possible bacterial concentration and the efficiency with which the bacteria were gotten into suspension. Even at a dilution of $1: 10^{14}$, the colonies in the plate were much too thick to count. Estimating the number of colonies at 1,000,000 the maximum concentration obtainable in the box would be $10^{17}$ bacteria per liter as compared with 73,233 , the maximum concentration actually obtained.

There was also considerable irregular variation in the persistence of the suspension even when the fan in the box was handled in the same way. The percentage ratio of the concentration at 20-25 minutes to that at $0-5$ minutes is listed in Table 6 under the head of "Percentage of Original Concentration." The values for the "Percentage of Original Concentration" are shown below:
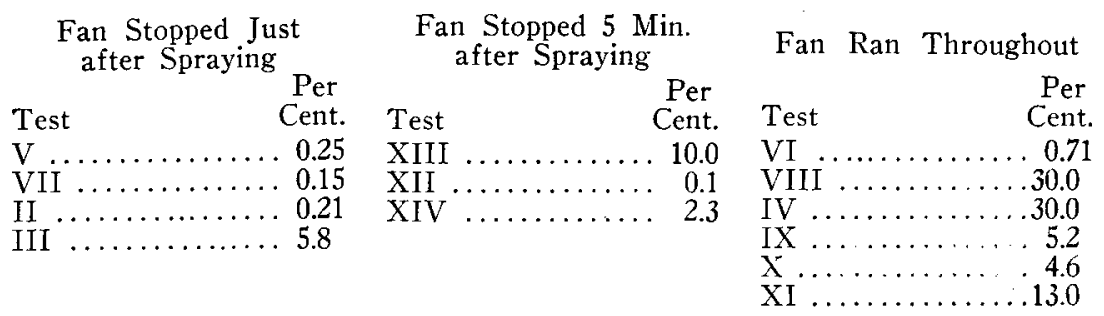

From these figures it is evident that the fan helps to support the suspension.

The decreased number of live bacteria found in the air at 20 minutes could, of course, be accounted for by the death of the bacteria as well as by their falling out. However, since in some instances the percentage of original concentration is as high as $30 \%$ at 20 minutes it seems likely that the decrease could be accounted for solely by the falling out of the bacteria in suspension. It is believed that the bacteria out in the open air would remain in suspension longer than in a box such as was used, since in the box they are constantly being blown against the top and sides to which they adhere. 
Comparison of Penetrating Power of Ist and and Sample.-In general, a higher percentage penetration was obtained for the second or drier sample than for the first. It is certain that the sample taken after 20 minutes was as dry, and therefore as penetrating, as the bacteria of similar size to be found in ordinary air.

Mask Recommended.-On the basis of the information presented in this article we have prepared masks with filters made from the hard felt. The filters have an area of approximately 125 sq. in., thus giving a much lower rate of air flow in actual breathing than that used in the bacterial tests. The pressure drop for the whole mask at ordinary breathing rates is only about 1 inch of water. These masks are available for test by suitable hospital authorities if desired.

\section{SUMMARY AND CONCLUSION}

Tests have been made to determine the degree of protection offered by various filtering materials against suspensions in air of B. prodigiosus.

Buttercloth masks have been found to give inadequate protection against bacteria in this form.

Felts are available which give complete protection against airborne bacteria of the size of $B$. prodigiosus.

The portable electrical precipitation apparatus of Dr. Lamb gives complete protection against bacterial suspensions, killing the bacteria in its action.

A mask with a felt filter with an area of 125 sq. in. and a pressure drop of about 1 inch of water has been constructed which will give complete protection.

The efficiency of the buttercloth filter is greatly increased by wetting the cloth. It might be possible to arrange an efficient wet filter mask which would be much simpler, more comfortable, and cheaper than those in which felt is used. 